\title{
The Dynamics of Change Agenda: The Contemporary Experience
}

\author{
Olusola Igbari \\ Crowther Graduate Theological Seminary, Abeokuta, Nigeria \\ Email: igbarisola@gmail.com
}

How to cite this paper: Igbari, O. (2018) The Dynamics of Change Agenda: The Contemporary Experience. Open Access Library Journal, 5: e4964.

https://doi.org/10.4236/oalib.1104964

Received: October 8, 2018

Accepted: November 16, 2018

Published: November 19, 2018

Copyright $\odot 2018$ by author and Open Access Library Inc.

This work is licensed under the Creative Commons Attribution International License (CC BY 4.0).

http://creativecommons.org/licenses/by/4.0/

(c) (i) Open Access

\begin{abstract}
Change is a universal phenomenon and an inevitable human experience which consequences can either be negative or positive. It is the only thing that is permanent in the journey of life of every individual created by God. The place of change in the leadership of any religious organisation or in any political party as it were cannot be over emphasized. The change is in all human facets, physically, spiritually, economically, politically and even culturally. This paper therefore examines what change in leadership can bring on the governed both in Politics and Religion. It also discusses some challenges and prospects that could emerge as a result of the change agenda. Humans by our nature clamour for change when people feel that the leadership in the church or in society has failed to meet up with their expectations. This is the dynamism inherent in human existence. Personal development is characterized by the values of personal identity influenced by the integrity of the leader in any human institution. The aspect of dynamic balance in the relationship with God is based on the value of God-centeredness in the life of a religious or secular person. This balance also brings dynamic relationship with the community based on the values of sacredness of human life, empowering love, freedom and justice for all. In consequence of this, balanced relationship between a wholesome person and the rest of the creation is based on the values of care for nature, maximization of resources and excellence which every individual and every community strives to attain. These are part of the values; change can bring into the lives of humans either in religion or in politics which on the other hand may not occur, if change is not dynamic.
\end{abstract}

\section{Subject Areas}

Politics

\section{Keywords}

Change, Dynamism, Leadership, Religion, Politics 


\section{Introduction}

The creation of humans by God from the beginning was to provide God's delegated authority on earth. Man was to exercise dominion over other creatures and to determine the state of affairs on earth (Gen. 1: 27 \& 28). Hence leadership gives shape and form to any organisation or community. It is a statement of fact that there is no human person that does not belong to a religion and a community where people are either appointed or elected into leadership positions.

The survival of a nation or a people is tied to the quality of leaders of such nation or people. Leadership is what determines the destiny of a nation or a people. When a leader fails in fulfilling the expectations of the followers, there will be a need to clamour for change. When change is effected, people become relieved psychologically at least for some time before they continue to discover who the new leader really is. This is the kind of dynamism in the nature of humans. This paper therefore discusses the challenges and the prospects of change agenda either in religious or political leadership. Before we go into the main thrust of this paper, I wish to give brief definitions of operational key words used in this paper.

\section{Leadership}

Several definitions have been given by scholars to describe what leadership means. In fact, Joanne Chilla quoted a study by Rost of 221 definitions of leadership which confirm the point that there is not a common definition of leadership [1]. Whatever definition given is the perspective of that person's personal conviction.

Leadership in another context may not be seen as a position in society, but doing something unusual, taking an initiative which nobody has done before. It is an activity of an ordinary citizen taking an initiative and generating a socially useful outcome. It is such a conception of leadership that allows both the President and a clerk in the society to exercise leadership regardless of their status in life. This sort of leadership is often anchored on core values and driven by a modicum of ideological convictions.

Leadership is also the state of being at the helm of affairs of any given organisation or a community. It is the function of the designated position and the exercises of the responsibilities involved in that position. It is God's own way of fulfilling His purpose for His creation. The plan or purpose of God for leaders is very clear. Bill Newman in the 10 laws of leadership said "a leader is one who knows the way, goes the way and shows the way" [2].

Every leader is an appointee of God. Leadership at all levels is stewardship and it is accountability. In the words of GbileAkanni, leadership maturity in a Christian community is God's channel in reaching out to men anywhere. It stands as the only possible means of growth of any Christian community [3]. This statement is valid in the sense that the Christian community is the product of what the leader is. 
Leadership is a dedicated position in the sense that leaders ought to communicate to subordinates with much care and attention as they communicate to superiors [4]. In fact in my own point of view, leadership is communication. Any breakdown in communication can lead to the collapse of the organisation. In order to be a leader, a man must have followers in whom he can repose his confidence [4] [5].

Leadership is indeed a task, a grave task and all efforts are expected to be generated towards the tasks that would make the vision and mission accomplished.

A leader who is a prisoner of his own conscience cannot stand up to defend righteousness among the people he is leading. The habit of life that reduces a leader's personal competence and integrity does not enhance a leader in leadership. He must be free from sin and sinful habits. He must not be a moral disgrace to himself and to the office he holds. He must be a man of integrity [6].

\section{Change}

Change implies all variations in human societies. When change occurs in the modes of living of an individual, it is referred to as social change.

The word "change" denotes a difference in anything observed over some period of time. Hence change could mean observable differences in any human experience over a period of time.

Whenever one finds that a large number of persons are engaged in activities that differ from those which their immediate forefathers were engaged in sometimes before, one can find what is called social change. Change is involved in variations from the accepted mode of life, where due to alternations in geographical conditions, in cultural equipments, composition of the population or ideologies which brought about diffusion on inventions within the group.

\section{Major Characteristics of Change}

1) Social: Change is always expressed in the lives of humans manifested through relationships, activities, growth and development. Hence any change agenda always affect the people positively or negatively.

2) Universal: Change is a universal phenomenon. It cuts across people irrespective of race, culture, religion, sex, institutions etc. anywhere anytime. It is universal and dynamic. No human experience is static.

3) Natural: Change is the law of nature. It is an unavoidable and unchangeable human experience. By the nature of humans, we deserve change. Human needs keep changing so as to satisfy our desire and to satisfy these needs change becomes inevitable e.g. raining and dry seasons are necessary for agricultural purpose.

4) Continuity: Change is continuous and it is also permanent. The society is an ever changing phenomenon. Change is undergoing endless process in human existence. It is an ongoing process and cannot be stopped as far as the earth endures. The meaning of continuity here is permanence. 
5) Peaceful or Violent: Change can be peaceful, it can be violent. It depends on the premise on which that change is effected. Change is peaceful when the parties involved in the change are ready to accommodate what the change can bring upon those concerned either favourable or unfavourable. Change is said to be violent if there are aggressive reactions from both parties involved. When it is violent, it is when threat or use of physical force is involved in achieving a given change. Whether change is peaceful or violent, it is an experience that has to take place so that change can be what it is.

Change in another context is becoming different. It is to alter an idea or a philosophy of life that brings different results, to modify a method to achieve a purpose or a desired end. In the context of this paper, it is initiating a different policy from the already existing one to achieve a desired goal.

Reactions to change by humans is one of the psychological experiences of man as he journeys through life, hence, change is seen as a more permanent human experience that makes or mars his destiny. According to David J. Atkinson and David H. Field, change in some situations can cause a psychological disconnect because what the change has brought may be more negative on the life of the individual than before the change emerged. This experience can trigal impaired personality [7]. Therefore, change in whatever context must be gradual to enable people adjust to the new experience. As far as the earth endures, change continues to be an essential part of human experience.

\section{Religion}

Religion is a broad concept which is difficult to define. Pascal Boyer defines religion as a psychological mechanism shared by all normal human beings. According to him, he is convinced of the inseparability of religion from normal human living and argues that religion is the fabric of people's lives strongly tied to their cultural identities as well as their efforts to survive amidst lives contingencies and insecurities [1] [8]. Religion is also seen as a form of behaviour, process or structure of which orientation is at least partially supernatural. Religion can also be said to be a set of rituals, rationalized by myth, which mobilizes supernatural power for the purpose of achieving the transformation of the state of humans or nature.

In essence, religion performs two basic functions for humanity which are:

The heavenly or spiritual function, which determines the relationship between man and God. While the earthly or social function which regulates relationships between and among human beings [1] [8] [9].

By implication, Religion evolves round the human person either in his relationship with the Supreme God or in his dealing with fellow human beings. Religion cannot exist without man so also man cannot exist without religion. The words "religion" and "religious" seldom appears in the scripture. This is at least partially because biblical faith is best understood as a relationship and thus stands in distinction from all religions of the world [10]. However, where the 
word "religion" is found in the New Testament, several Greek words are used. For instance, in Acts 25: 19, Judaism is called by an outsider $\delta \varepsilon \iota \zeta \boldsymbol{\iota} \boldsymbol{\alpha} \boldsymbol{\gamma}$ vovı $\boldsymbol{\alpha}$

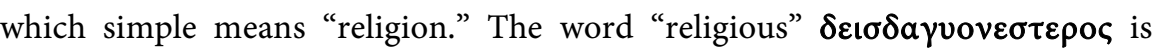
found in Acts 17: 22 where Paul began his sermon in Athens by calling attention to evidence that the Greeks were "very religious" [10] [11].

Religion is historical in the sense that it arises as the consequences of certain events in history and in the sense that its shape and content are determined by the events. In religion, there is response on the part of the adherent and there is mutuality between the Ultimate Being and the religionist.

Geoffrey Parrinder defines religion as: "The recognition of superhuman controlling power, and especially of a personal God, entitled to obedience" [12].

The concept of any religion involves higher being working out His purpose in the life of the adherents and who is also entitled to be obeyed. This forms the content of any religion, hence religion is universal and it cuts across all stages of history and human geography.

In Parrinder's view, the study of religions reveals that an important feature of it is a longing for value in life, a belief that life is not accidental or meaningless. He says:

The search for meaning leads to faith in a power greater than man, and finally to a universal or superhuman mind which has the intention and will to maintain the highest values for human life. There is an intellectual element in religious search for purpose and value and an element in the dependence upon which creates or guarantees those values [12] [13].

A philosopher, A.N. Whitehead defines religion as what "the individual does with his own solitariness" [12] [13] [14]. His definition is incomplete in my own point of view in the sense that religion always has a social content and it is expressed in patterns of behaviour. Sometimes, there is a strong organisation, such as a church or mosque while at other times the model of religious life can be that of a lone life in the forest. Herber Spencer says, "Religion had its origins in vision or appearance of the ghost of the dead, and these ancestors were worshipped as gods" [12] [13] [14] [15]. This is true of what religion is especially in the traditional context.

Emile Durkheim says "Religion is a social fact and not simply the product of psychology of certain individuals." According to him, it could not be an illusion, for religion was universal and had appeared in every age, producing great cultures and system of morality and law [16].

In these definitions from different scholars, one can conclude that religion started with the creation of humans and it will continue to endure as far as man remains on earth. By implication, it is when man ceases to exist on the surface of this earth planet that religion will also cease to be in existence.

\section{Leadership, Change and Religion Nexus}

In contemporary experience, humans do clamour for change in leadership both 
in religious organizations or in politics. The reason being that people want change to take place whether it is necessary or not. As mentioned earlier in this paper, change is an inevitable phenomenon that characterizes the life of humans. The expectation is that the change will definitely bring new hopes either on temporary or permanent basis. Most people, even among scholars forget that at the core of any developmental challenge is a perennial clash of ideologies. The ideology of a change agent in a religious sphere may clash with the ideology of the former leader which invariably can bring dissatisfactions to the people who clamour for that change.

According to Aderinwale, "Our clash of civilization predates the American clash of civilization, which has produced their own end of history" [17].

In his view, change can bring a clash of civilization which can equally reshape the destiny of an individual or even a nation. Hence, change is a powerful tool, event or action that produces what one becomes.

Let us examine this question, "What kind of leadership and religious practice will make our democracy sustainable in Nigeria?" The answer to this question is not far-fetched from the political experiences Nigeria has gone through in the last sixteen years. It is a government that entrenches moral values in the culture of governance.

Religion is said to be a way of life based on certain core values which equally emphasizes interpersonal relationship and principles which are non-negotiable. Leadership similarly, and particularly leadership based on core positive values is aimed at generating socially useful outcomes that satisfies and meets the needs of both the leaders and the led.

In Africa, let us examine the interplay in terms of leadership, change and religion. The dominant and modern religions in Africa today were imported into the continent from other regions of the world. Thus, the ethos of "imported modern religious ideas" and persisting indigenous religious ideas seem to be locked in a permanent struggle for approximation.

In Aderinwale's words,

The preponderance of hybrid religious ideas and the seeming poor clarification of the contending contradictions, give rise to several values and principles that seemingly guide the attitudes and mindsets of several actors and factors which goad the continent towards fulfillment and unfulfilling as the case may be [17] [18].

Invariably, the change in mode of worship, beliefs and practices brought by imported religions which sometimes conflict with African way of doing things do bring contradictions especially where the tenet of such religions are not clearly stated. In my own critical assessment, this is the heart of the problem confronting most Africans.

Religious leaders in some regions of the world have severally managed to conduct themselves in a manner that makes them clearly above board in charac- 
ter and learning. Thus, they have the moral standpoint to insist on proper conduct and behaviour by the political leaders. Unfortunately, in some quarters, the cassocks in most churches drip with sinful conduct. Some of the so-called religious leaders have brought all manners of profanities to the temple. Some contemporary religious leaders have mastered the art of deceit, make believe gimmicky. They appear mostly to be intendant newer emerging pastorpreneurs of the redoubtable American Pentecostalism whose major focus is more on the entrepreneurial aspect than on the pastoral calling [19]. According to Aderinwale, "In effect, the utility and functionality of religion as an effective mobilization instrument has been thoroughly abused, diminished and devalued."

Sadly in Africa, the prevailing atmosphere of economic decline makes the people increasingly religious. Hence, there is astronomical increase in the population of the religious people i.e. church goers and a decline in the population of those who are spiritual. The shame which calls for concern is that the progressive revolutionary forces in Africa have never been able to utilize religion as change agent in enforcing moral values on governance. For example in Latin America, Catholic Fathers were said to have utilized their vantage position to inbreed a certain conscience and mobilize their adherents in the political struggle against oppression and other forms of venality, maladministration and general incompetence on the part of the political leaders.

Also in Africa, there is apparent disregard for ethical consideration and public-spiritedness predominant among some of our past and current generation of leaders both in the Church and the government which is a pointer to a disintegrating society and a bleak future. This is a serious challenge. Without an ethical revolution and a total orientation, the system will only continue to recycle itself and the state of governance both in the church and $n$ the state will remain in jeopardy. The fact remains that leadership without a positive value anchor will not facilitate sustainability.

Leadership without meaningful participation of the followers irrespective of whatever change agent that is involved will be abstract, puerile, meaningless and exploitative. In similar vein, religion without spirituality has no effectual value in moderating interpersonal interaction and serving as a curb on the excesses of men and women in power.

\section{The Dynamics of Change Agenda: The Contemporary Experience}

In this key section of the paper, I wish to examine dynamism in relation to change agenda of the democratically elected government and the impact on the electorate.

Humans are inherently dynamic in nature; so also human experience in one's journey of life is also dynamic. Democratic government is the government of the people, by the people and for the people. If this is so, then a democratically elected government as we have it today in Nigeria should be sensitive to the 
needs of the people they govern and put in place people-oriented-programmes that will make everyone enjoy dividends of democracy. The content of any change agenda is vital to the survival of any administration either in the church or in the state. The content is expected to be geared towards the realization of people's aspirations.

The word "Agenda" here means "organised plan for matters to be attended to," it is a list of issues to be taken up at a meeting or at a conference. It is a schedule, docket, work list or temporarily organized plan geared towards achieving a vision.

Change agenda is to effect a different method from the usual way of doing things so as to achieve unusual results. In the context of the contemporary experience, Nigeria is going through a kind of overhauling with the intention of having it better than it was before in all spheres of human endeavours. Issues of insecurity of life and property, provision of infrastructure, health care facilities, education, access to freedom of worship, adequate power supply, effective transportation system, agriculture, economic buoyancy, peaceful co-existence, provision of housing facility, and so on become the central focus of any change agenda. These are what people expect as dividends of democracy.

Exploring into the history of elections down the ages, one discovers that there had been a formal process of selecting a person for public office or of accepting or rejecting a political agenda by voting. What informs the decision of the electorate at any election is based on the presentation of proposed agenda of the party or the individual involved. This also makes the voters to have free and genuine choice at least between two alternatives.

In the contemporary world, there is gradual emergence of representative government in Europe and North America beginning from the $17^{\text {th }}$ Century [20]. At that time, the holistic notion of representation characteristic of the Middle Ages was transformed into a more individualistic conception, one that makes the individual the critical unit to be counted. During the $18^{\text {th }}$ Century, access to the political arena depended largely on membership of a political party and participation in elections was regulated mainly by local customs and arrangements. The vote of a voter remained an instrument of political power possessed by an individual, and this instrument is used to bring on board the political agenda that favour the aspirations and expectations of the electorate.

In the $19^{\text {th }}$ and $20^{\text {th }}$ Centuries in the western world, elections had quite different purposes and consequences under the one party communist's regimes of Eastern Europe and the Soviet Union during the period from the end of World War II to 1989-1990 [20] [21]. In the late 1970s elections were introduced in some African Countries when military dictatorship were dissolved e.g. Nigeria and Ghana.

In these places electioneering campaigns feature manifestoes that could attract voters to voting either for the nominated candidate or for the party he belongs. Hence, the place of proposed political agenda becomes prominent in the success 
of any political party. Thus elections based on desired political agenda of a party or individual makes a fundamental contribution to democratic governance. It also reinforces the stability and legitimacy of the political community.

In the last sixteen years of democratic rule in Nigeria, people have always reacted negatively at different times to regimes that experienced failed agenda. The immediate consequence is aggressive reactions of the people either by expressing themselves in riotous public rallies, embarking on strikes, making use of media, electronic or print and using other available means of negative reactions as a signal to the government that change agenda is desired as a relieve to the people.

"Change agenda" is very important in governance if genuine democracy is expected to offer dividends to the voters who used their votes to determine their destiny.

The political experience in Nigeria today is daisy in the sense that people seem not to known yet the would-be outcome of the efforts the government in power is making to re-fix Nigeria. This calls for patience and co-operation on the part of the people.

\section{Conclusion}

It should be noted that any change agenda either in politics, religion, economy and in social life suggests the pattern of growth of the sector involved. As emphasized in this paper, any change agenda embarked upon for governance informs the success or failure of any government. Therefore, leadership in any human institution should always be sensitive to the needs of the people they govern to ensure true and genuine democracy. Our democracy in Nigeria in my own assessment is still under trial. Absolute confidence of the people is not yet entrenched in the minds of Nigerians until we have a government that will effect people-oriented programmes that can enhance growth and development of the nation.

\section{Recommendations}

This paper therefore recommends:

1) That our political leaders in Nigeria should have listening hears and not to ignore the psychological trauma that the masses go through especially when hardship continues to mount for instance, the recent issue of hike in pump price of fuel.

2) That moral values be firmly entrenched in the culture of governance through religious channels or platforms so that leaders can maintain integrity and decorum that can sustain people's confidence.

3) That the rule of law be obeyed by the leaders to enthrone sanity in our political terrain so as to ensure political stability that Nigerians long for in the nation.

4) That growth and development which is the ultimate goal of every Nigerian 
should top the list of the political agenda of the leaders to ensure dividends of democracy for the citizenry.

That a leader who has lost his integrity in governance due to alleged misdemeanor be encouraged to resign honorably as it usually happens in the Western world instead of sticking to his seat without sense of remorse. The continuous stay in office of such a leader who has dented the image of his office is a show of lack of shame and a celebration of illegality in governance which invariably gives a bad image to the entire nation at the global level.

\section{Conflicts of Interest}

The author declares no conflicts of interest regarding the publication of this paper.

\section{References}

[1] Adadevoh, D., Ed. (2009) Religion and Government in Africa: Christian Response. ILF Publishers, Orlando, 164.

[2] Newman, B. (1992) 10 Laws of Leadership. BNC Publications, Toowrongs, 7.

[3] Akanni, G. (2010) Pathway to Leadership. Peace Home Publications, Gboko, 10.

[4] White, J. (1988) Excellent in Leadership. I.V.P., London, 12.

[5] White, J. (1988) Excellent in Leadership. I.V.P., London, 13-14.

[6] Inrigs, G. (nd) Quality Friendship. Moody Press, Chicago, 32.

[7] Atkinson, J.D. and Field, H.D. (1995) New Dictionary of Christian Ethics and Pastoral Theology. Inter Varsity Press, Leicester, 300.

[8] Adadevoh, D., Ed. (2009) Religion and Government in Africa: Christian Response, ILF Publishers, Orlando, 165.

[9] Adadevoh, D., Ed. (2009) Religion and Government in Africa: Christian Response, ILF Publishers, Orlando, 166.

[10] Richard, O.L. (1977) Religion' Expository Dictionary of the Bible Words. Zondervan Publishing House, Grand Rapids, 519.

[11] Richard, O.L. (1977) Religion' Expository Dictionary of the Bible Words. Regency Reference Library, Grand Rapids, 520.

[12] Parrinder, G. (1971) Man and His Gods. Encyclopedia of the World Religions, The Hamlyn Publishing Group Ltd., London, 9.

[13] Parrinder, G. (1971) Man and His Gods. Encyclopedia of the World Religions, The Hamlyn Publishing Group Ltd., London, 10.

[14] Parrinder, G. (1971) Man and His Gods. Encyclopedia of the World Religions, The Hamlyn Publishing Group Ltd., London, 11.

[15] Parrinder, G. (1971) Man and His Gods. Encyclopedia of the World Religions, The Hamlyn Publishing Group Ltd., London, 11.

[16] Durkheim, E. (1912) The Elementary Forms of Religious Life.

[17] Aderinwale, A. (2009) Religion, Leadership and Democratic Sustenance in Africa. ILF Publishers, Orlando, 169.

[18] Aderinwale, A. (2009) Religion, Leadership and Democratic Sustenance in Africa. ILF Publishers, Orlando, 170. 
[19] For More Elaborate Analysis on This Emerging Phenomenon, Please See the Economist (February 23, 2006), Jesus, CEO: Churches as Businesses. Economist Newspaper Ltd. http://www.economist.com

[20] Eulau, H., Gibbins, R. and Webb, P.D. (2010) Elections. Encyclopedia Britannica, Chicago, 2.

[21] Eulau, H., Gibbins, R. and Webb, P.D. (2010) Elections. Encyclopedia Britannica, Chicago, 3. 